\title{
Frequency of congenital heart disease among patients with Down's syndrome in Mosul
}

\author{
Zaid Moayad Yassen*, Mazin Mahmoud Fawzi“*, Rayan Salim Alsaoor*** \\ * Department of Family and Community Medicine, College of Medicine, University of Mosul, ** Department of \\ Pediatrics, College of Medicine, University of Mosul, ${ }^{\star \star \star}$ Al-Khansaa Teaching Hospital, DOH, Mosul, Iraq. \\ Correspondence: Zaid Moayad Yassen. zaidyassen67@yahoo.com.
}

(Ann Coll Med Mosul 2018; 40 (2): 24-28).

Received: $12^{\text {th }}$ Nov. 2013; Accepted: $4^{\text {th }}$ Apr. 2014.

\section{ABSTRACT}

Background: Down's syndrome (DS) or trisomy 21 is a chromosomal disorder frequently associated with a varied combination of morphological and structural birth defects. Individuals with Down syndrome are more prone to congenital heart defects such as atrioventricular septal defects (ASD), ventricular septal defects (VSD), isolated secundum atrial septal defects. Congenital and acquired gastrointestinal anomalies and hypothyroidism are common in patient with DS.

Aims: To measure the frequency of congenital heart disease (CHD) among study population, to categorize $\mathrm{CHD}$ according to their anatomical location and to demonstrate socio-demographic characteristics of Down syndrome patients.

Methods: Case series study design was conducted in Mosul over one year period starting from the $1^{\text {st }}$ of Dec. 2011 to the $30^{\text {th }}$ of Nov. 2012. Parents have been intervened by one of the investigators, and a specially designed questionnaire form were completed to each patient.

Echocardiography have been conducted to all patients included in the study by a qualified pediatric cardiologist in Echo Unit- Khansaa Teaching Hospital, the echo result was recorded in the questionnaire form. Analysis of the data was conducted by using SPSS, and excels computer systems; simple rates and ratios were calculated in order to describe the study findings.

Results: The present study includes a total of 69 patients diagnosed with Down's syndrome. Two thirds of study population was below six months of age. Male gender constitutes $69.6 \%$ of study population with male to female ratio $1: 0.44$. $39.2 \%$ of mothers are in age group $\geq 40$ years. Fifty patients $(72.5 \%)$ with DS diagnosed to have CHD by echocardiography. ASD was the most common defect and was diagnosed among $30 \%$ of patients, followed by complete AV canal and VSD which constitutes $20 \%$ each. $14.5 \%$ of patients with DS have extra cardiac anomalies and GIT anomalies were the most frequent one.

Conclusion: The incidence of congenital heart disease in patients with Down's syndrome was high in this study (72.5\%). ASD was the most frequent form observed.

Keywords: Down's syndrome, CHD.$$
\text { نسب حدوث أمراض القلب الولادية لاى المصابين بمتلازمة داون في الموصل }
$$

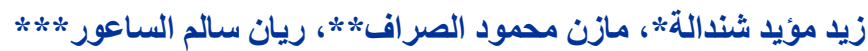

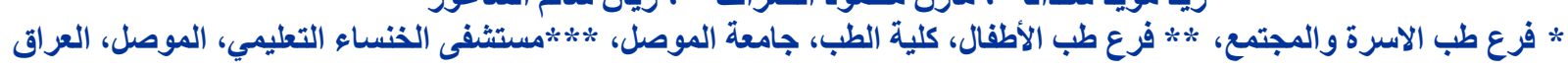

الخلفية: متلازمة داون او تثلث الصبغي آ هو اضطر اب في الكروموسومات يرتبط غالبا مع مجموعة من العيوب المورفولوجية

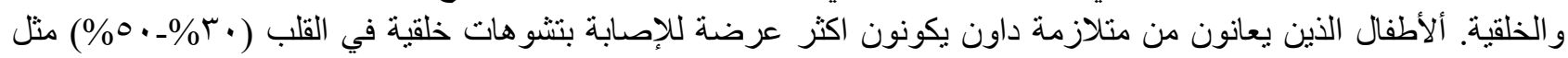


عيوب الحاجز الأذيني البطيني، عيوب الحاجز البطيني، وعيوب الحاجز الأذيني . كما أن التشوهات الخلقية للجهاز الهضمي ونقص هرمون الغدة الدرقية تعتبر شائعة للمرضى الادئ المصابين بمتلازمة داون.

أهداف البحث: لقياس نسبة تكرار تشو هات القلب الخلقية لمرضى متلازمة داون قيد الدر اسة، لتصنيف نشوهات القلب الخلقية وفقا

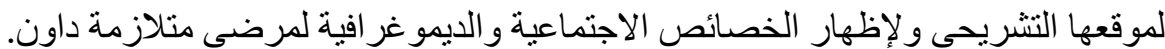

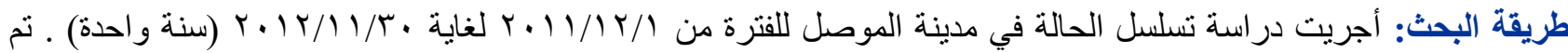
تضمين جميع المرضى المصابين بمتلازمة داون في الدراسة وتم أخذ المعلومات الطبية من أحد الوالدين حسب إستمارة إستبيان

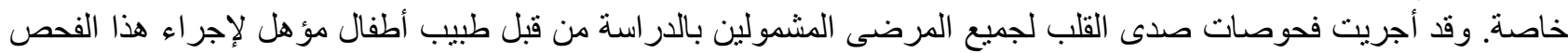

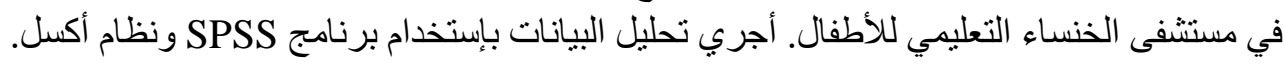
النتائج: شملت هذه الدر اسة 97 طفل مصاب بمتلازمة داون وكانت أعمار ثلثي الأطفال المصابين أقل من ستة شهور ـ كانت نسبة

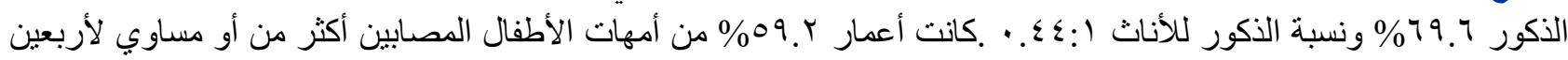

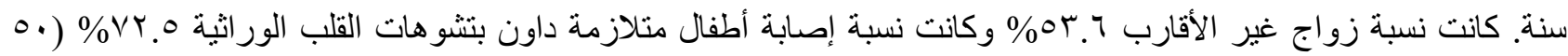

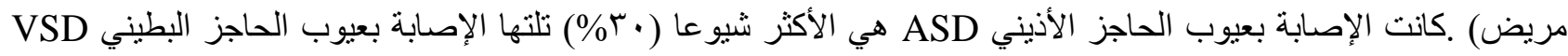

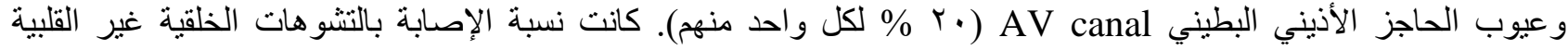

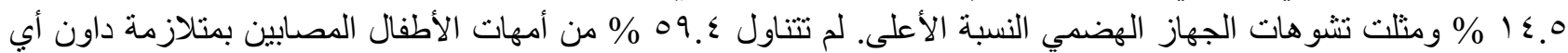
علاجات أثناء الحمل . ألاستنتاجات: كان نسبة الإصابة بتشوهات القلب الخلقية عالية في هذه الدراسة ه هY\% وكانت الإصابة بعيوب الحاجز الأذيني ASD

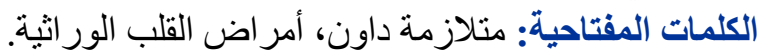

\section{INTRODUCTION}

$\mathrm{T}$ risomy 21 or Down syndrome (DS) is a chromosomal disorder commonly related with a varied mixture of morphological and structural birth defects in the form of congenital intellectual disability, hypotonia, distinguishing body features, heart defects, and other inherited malformations. The occurrence of these morphological and functional problems vary considerably among affected individuals. ${ }^{1}$

In 1866, John Langdon Haydon Down first characterize DS as a dissimilar disease with intellectual impairment then in late fifties, Lejeune and Jacobs separately reported that DS resulted from additional chromosome 21. In view of the fact the condition has been known as trisomy $21 .{ }^{1}$ This particular trisomy is the most widespread form of chromosomal abnormality, affecting about one in 700 live births ${ }^{2,3}$. It is characterized by the whole chromosomal aneuploidy in about ninety five percent of cases. The remaining five percent is in the form of translocations and mosaics ${ }^{4}$. The risk of pregnancy with DS increases with the mother's age, and it can occur with an incidence as high as one in 30 in those women older than 45 years ${ }^{1}$.

Individuals with Down's syndrome are more prone to congenital heart defects $(30-50 \%)$ such as atrioventricular septal defects, ventricular septal defects (VSD), isolated secundum atrial septal defects(ASD), patent ductus arteriosus (PDA), and tetralogy of Fallot (TOF). hereditary and acquired gastrointestinal anomalies and hypothyroidism are common ${ }^{5,6}$. the cardiac anomalies in mongolism appeared to be due predominantly to defects occurring in the earlier stages of cardiac development ${ }^{7}$.

Cardiovascular complications are vital in Down's syndrome. Children who seem asymptomatic at birth and do not have a murmur may have a major cardiac defect. If augmented pulmonary vascular resistance is noted, the left-to-right shunt may be minimized, thus preventing early heart failure. However, if left undetected, this condition may lead to constant pulmonary hypertension with irreversible pulmonary vascular changes. ${ }^{8}$ In patients with an ASD, symptoms usually occur in infancy as a result of systemic-to-pulmonary shunting, high pulmonary blood flow, and an enlarged risk of pulmonary arterial hypertension. Augmented pulmonary resistance may lead to a reversal of the systemic-to-pulmonary shunt accompanied by cyanosis ${ }^{8}$. 
Patients with Down's syndrome are considered to be at superior risk for pulmonary arterial hypertension than patients with no Down syndrome. For the reason that the low number of alveoli, the thinner media of pulmonary arterioles, and the impaired endothelial function. Timely corrective cardiac surgery is warranted to prevent irreversible pulmonary vascular lung damage ${ }^{9}$.

\section{Aims of the study:}

1- To measure the frequency of CHD among study populatiom.

2- To categorize CHD according to their anatomical location.

3- To demonstrate socio-demographic characteristics of Down's syndrome patients.

\section{PATIENTS AND METHODS}

The present study was conducted in Mosul over one year period starting from the $1^{\text {st }}$ of Dec. 2011 to the $30^{\text {th }}$ of Nov. 2012. Case series study design was adopted in order to achieve the objectives of the present study.

It was decided to include all patients who are diagnosed to have Down's syndrome by a qualified pediatrician through their consultation to pediatric units in Al-Khansaa Teaching Hospital in Mosul during the study period.

Informed consent has been taken from the parents before inclusion to the study.

Parents have been intervened by one of the investigators, and a specially designed questionnaire form were completed to each patient including age, gender, mother's age, father's age, child rank, drug history during pregnancy, family history of CHD. Furthermore echocardiography have been conducted to all patients included in the study by a qualified pediatric cardiologist in Echo Unit- Khansaa Teaching Hospital, the echo result was recorded in the questionnaire form.

Analysis of the data was conducted by using SPSS, and excels computer systems; simple rates and ratios were calculated in order to describe the study findings.

\section{RESULTS}

The present study includes a total of 69 patients diagnosed with Down's syndrome. Table 1 depict the characteristics of study population, it is clear from the table that two thirds of study population were below six months of age, on the other hand
$20.3 \%$ of study population were above 1 year of age. Moreover male gender constitutes $69.6 \%$ of study population with male to female ratio $1: 0.44$, also the table shows that $39.2 \%$ and $58.0 \%$ of mothers and fathers respectively were in age group $\geq 40$ years; age group $30-40$ years constitutes $33.3 \%$ and $26.0 \%$ of mothers and fathers respectively. Regarding parents consanguinity the table illustrate that more than half of study population $(53.6 \%)$ gave a negative history for parents consanguinity. Majority of patients have negative family history for CHD, only $10.1 \%$ of study population have a positive family history of CHD, see table (1).

Table 1. Sociodemographic characteristics of study population, Mosul 2013.

\begin{tabular}{lcc}
\hline $\begin{array}{l}\text { Characteristic } \\
\mathrm{N}=69\end{array}$ & No. & $\%$ \\
\hline Age (months) & & \\
\hline $0-6$ & 46 & 66.7 \\
$6-12$ & 9 & 13.0 \\
$\geq 12$ & 14 & 20.3 \\
\hline Gender & & \\
Male & 48 & 69.6 \\
\hline Female & 21 & 30.4 \\
\hline Mother's age & & \\
\hline 20 & & \\
\hline $20-30$ & 6 & 8.7 \\
\hline $30-40$ & 13 & 18.8 \\
$\geq 40$ & 23 & 33.3 \\
\hline Father's age & 27 & 39.2 \\
\hline$<20$ & & \\
$20-30$ & & \\
\hline $30-40$ & 1 & 1.5 \\
\hline 40 & 10 & 14.5 \\
\hline
\end{tabular}

Parents consanguinity

\begin{tabular}{|lcc|}
\hline Yes & 32 & 46.4 \\
\hline No & 37 & 53.6 \\
\hline Child rank & & \\
\hline $1-2$ & 20 & 29.0 \\
\hline $3-4$ & 14 & 20.3 \\
\hline $5-6$ & 9 & 13.0 \\
\hline+ & 26 & 37.7 \\
\hline
\end{tabular}

Family history of CHD

\begin{tabular}{lcc} 
Positive & 7 & 10.1 \\
Negative & 62 & 89.9 \\
\hline
\end{tabular}


Table 2 give a picture of distribution of Down's syndrome patients according to $\mathrm{CHD}$, it is evident that fifty patients $(72.5 \%)$ diagnosed to have $\mathrm{CHD}$ by echocardiography. Atrioseptal defect (ASD) was the most common defect and was diagnosed among $30 \%$ of patients, followed by complete AV canal and ventricular septal defect (VSD) which constitutes $20 \%$ each. On the other hand tetrology of Fallot (TOF) and patent ductus arteriosus (PDA) were diagnosed only in 4 patients $(8 \%)$ and 3 patients $(6 \%)$ respectively.

Table 3 portray the distribution of Down's syndrome patients according to other congenital anomalies, it is obvious that only 10 patients $(14.5 \%)$ have other congenital anomalies. Intestinal atrasia was diagnosed among 4 patients also anal atrasia was observed in 4 patients; moreover polycystic kidney and hydrocephalus were found in one patient for each.

Table 2. Distribution of Down syndrome patients according to CHD, Mosul 2013.

\begin{tabular}{lcc}
\hline $\begin{array}{l}\text { Congenital heart disease } \\
\text { N=69 }\end{array}$ & No. & $\%$ \\
\hline Present & 50 & 72.5 \\
Not present & 19 & 27.5 \\
$\begin{array}{l}\text { Type of CHD } \\
\text { N=50 }\end{array}$ & \\
ASD & 15 & 30 \\
Complete AV canal & 10 & 20 \\
VSD & 10 & 20 \\
ASD and VSD & 5 & 10 \\
\hline TOF & 4 & 8 \\
Incomplete AV canal & 3 & 6 \\
\hline PDA & 3 & 6 \\
\hline
\end{tabular}

Table 3. Distribution of Down syndrome patients according to other congenital anomalies, Mosul 2013.

\begin{tabular}{lll}
\hline $\begin{array}{l}\text { Congenital Anomalies } \\
\mathrm{N}=69\end{array}$ & No. & $\%$ \\
\hline Present & 10 & 14.5 \\
\hline Not present & 59 & 85.5 \\
$\begin{array}{l}\text { Type of Congenital anomalies } \\
\mathrm{N}=10\end{array}$ & \\
\hline $\begin{array}{l}\text { Intestinal atrasia } \\
\text { Anal atrasia }\end{array}$ & 4 & 40 \\
\hline Polycystic kidney & 4 & 40 \\
\hline Hydrocephalus & 1 & 10 \\
\hline
\end{tabular}

Tables 4 describe the distribution of Down's syndrome patients according to history of mother's drug intake during pregnancy, it is clear that $59.4 \%$ of mothers have a negative history of drug intake during pregnancy of this child. Twenty eight mothers have a history of drug intake during pregnancy, 18 mothers of them state that they take antibiotics, 5 mothers and 3 mothers ingest methyl dopa and progesterone respectively.

Table 4. Distribution of Down syndrome patients according to history of mother's drug intake during pregnancy, Mosul 2013.

\begin{tabular}{lll}
\hline $\begin{array}{l}\text { History of drug intake during } \\
\text { pregnancy } \\
\mathrm{N}=69\end{array}$ & No. & $\%$ \\
\hline Present & 28 & 40.6 \\
\hline Not present & 41 & 59.4 \\
$\begin{array}{l}\text { Type of drug intake } \\
\text { N=28 }\end{array}$ & \\
\hline Antibiotics & & \\
Methyl Dopa & 18 & 64.3 \\
\hline Progesterone & 5 & 17.9 \\
Beta agonist & 3 & 10.6 \\
\hline Non-steroidal anti inflammatory & 1 & 3.6 \\
\hline & 1 & 3.6 \\
\hline
\end{tabular}

\section{DISCUSSION}

Congenital heart disease is common in patients with DS and the incidence vary between 30\%-70\% 7,10 , the introduction of $2 \mathrm{DE}$ and Doppler echo provided means of early and accurate diagnosis of CHD. ${ }^{11}$

The incidence of congenital heart disease in this study found to be $72.5 \%$ which is higher than that reported by other studies from Malaysia $50 \%{ }^{12}$, Sudan $48 \%{ }^{13}$, Mexico $58 \%{ }^{14}$, and Saudi Arabia $63 \%{ }^{15}$. The high incidence of CHD in this study may attribute to the fact that this study was performed in a referral echo center for Mosul.

Down's syndrome is associated with advance maternal $\mathrm{age}^{5,6}$ and this agree with the present study in which $39.2 \%$ of cases of DS occurs in mothers aged 40 years and above. The majority of our patients were diagnosed with congenital heart disease during the first year of life (79.7\%), and this agrees with other study done in Mexico ${ }^{14}$. Male sex was predominant $(69.6 \%)$ and this agrees with other study done in Lebanon ${ }^{16}$. Parent's consanguinity was less common in patients with DS and CHD (46.4\%) and this agrees with other study from Lebanon which showed that the risk 
of congenital cardiac anomalies was not associated with parents consanguinity ${ }^{17}$.

Isolated ASD, VSD and complete AV canal accounted for $70 \%$ of the cardiac abnormalities observed in Down syndrome. The most frequent was isolated ASD (30\%) followed by VSD and complete AV canal (20\% for each). With regard to ASD, value reported in the present study in Mosul agrees with studies from Mexico ${ }^{14}$ and Libya $23 \%$ 1 , and disagree with others from Lebanon ${ }^{17}$, Ireland $^{18}$ Malaysia $^{12}$, and Tunis ${ }^{19}$. The types of cardiac malformation in DS can be determined by different factors like: Genetic factors, specific embryological mechanisms, and cell characteristics. Nevertheless, ethnic and geographic factors may also influence the formation of these abnormalities ${ }^{14}$.

The most frequent extra cardiac malformations observed in the present study were related to the digestive tract $(80 \%)$ with intestinal atrasia and anal atrasia were the most frequent forms $(40 \%$ for each) a finding consistent with results reported in literatures from Saudi Arabia $^{15}$ and India ${ }^{20}$.

The present study revealed that $59.4 \%$ of mothers have a negative history of drug intake during pregnancy of the Down's child and this agrees with the fact that the only maternal risk factors are advance age and chromosomal translocation $^{9,21}$.

\section{CONCLUSION}

The incidence of congenital heart disease in patients with Down's syndrome was high in the present study (72.5\%). ASD, complete AV canal and VSD accounted for $70 \%$ of Down syndrome heart abnormalities in the present study setting. Isolated ASD was the most frequent lesion (30\%). GIT anomaly was the most frequent extra cardiac anomalies observed.

\section{REFERENCES}

1.Elmagrpy Z, Rayani A, Aburawi EH. Down syndrome and congenital heart disease: why the regional difference as observed in the Libyan experience? Cardiovasc J Afr. 2011 November; 22(6): 306-309.

2. Hoffman JI. Incidence of congenital heart disease. J Am Coll Cardiol. 2002;39:1890-1900.

3.Hoffman JI. Paediatric Cardiology. $2^{\text {nd }}$ ed. Vol. 1. Philadelphia: Churchill Livingstone; 2002. Incidence, mortality and natural history. pp. 111-131.

4. Hamertone JL, Briggs SM, Giannelli F, Carter CO. Chromosome studies in detection of parents with high risk of second child with Down syndrome. Lancet 1961;2:788-791.

5.Judith G. Nelson test book of pediatrics. $17^{\text {th }}$ ed. Elsevier Saunders.2000, chapter 70, chromosomal clinical abnormalities; p.383-390.

6.Lissauer T. Clayden G. Illustrated text book of pediatrics. Mosby Elsevier. $3^{\text {rd }}$ ed, 2009.

7.Philip R. Cardiac anomalies in Mongolism. Br Heart J. 1950 July; 12(3): 258-262.

8.Vis JC, Duffels MG, Winter MM, Weijerman ME, Cobben JM, Huisman SA, Mulder BJ. Down syndrome: a cardiovascular perspective. J Intellect Disabil Res 2009; 53(5):419-25.

9. Harold Chen, Bruce Buehler. Down's syndrome. http://emedicine.medscape.com/article/943216-

overview. Accessed on 1/11/2013.

10.Jesús de Rubens Figueroa, Blanca del Pozzo Magaña, José L. Pablos Hach, Claudia Calderón Jiménez, and Rocío Castrejón Urbina. Heart Malformations in Children With Down Syndrome. Rev Esp Cardiol 2003;56(9):894-9.

11.Lo Ngok Sing Roxy, Leung Ping Maurice, Lau Kai Chiu and Yeung Chap Yung. Congenital Cardiovascular Malformations In Chinese Children With Down's Syndrome. Chinese Medical Journal 1989;102(5):382386.

12. Hoe TS, Chan KC, Boo NY. Cardiovascular malformations in Malaysian neonates with Down's syndrome. Singapore Med J. 1990;31(5): 474-6.

13.Sulafa KM. Cardiac abnormalities of Sudanese patients with Down's syndrome and their short-term outcome. Cardiovasc J Afr 2009; 20: 112-115.

14.Jesús de Rubens Figueroa, Blanca del Pozzo Magaña, José L. Pablos Hach, Claudia Calderón Jiménez, and Rocío Castrejón Urbina. Heart Malformations in Children with Down syndrome. Rev Esp Cardiol. 2003;56 (9):894-9.

15.Abbag FI. Congenital heart diseases and other major anomalies in patients with Down syndrome. Saudi Med J. 2006;27(2):219-22.

16.Chéhab G1, El-Rassi I, Abdo A, Fakhoury $\mathrm{H}$, Chokor I, Haddad W, Saliba Z, et al. Atrioventricular septal defect characteristics in infants with and without Down's syndrome: a Lebanese study. J Med Liban 2010;58(1):3-7.

17.Chéhab G, Chokor I, Fakhouri H, Hage G, Saliba Z, El-Rassi I. Congenital heart disease, maternal age and parental consanguinity in children with Down's syndrome. J Med Liban. 2007;55(3):133-7.

18.T R J Tubman, M D Shields, B G Craig, H C Mulholland, N C Nevin. Congenital heart disease in Down's syndrome: two year prospective early screening study. BMJ 1991;302:1425-7.

19.Abid D, Elloumi A, Abid L, Mallek S, Aloulou $\mathrm{H}$, Chabchoub I, et al. Congenital heart disease in 37,294 births in Tunisia: birth prevalence and mortality rate. Cardiol Young 2013; 8:1-6.

20.Kava MP, Tullu MS, Muranjan MN, Girisha KM. Down syndrome: clinical profile from India. Arch Med Res. 2004;35(1):31-5.

21. Charlotte A. Polymorphisms in Genes Involved in Folate Metabolism as Maternal Risk Factors for Down Syndrome. Am. J. Hum. Genet.2000; 67:623-630. 